\title{
O livro didático no ensino-aprendizagem de leitura em língua estrangeira: conceitos em foco
}

\author{
Marcel Alvaro de Amorim \\ UFRJ / UFF/ UniFOA
}

\author{
Alvaro Monteiro Carvalho \\ UFRJ / PMBM / IBEU
}

\begin{abstract}
Resumo
Este trabalho tem como finalidade analisar as atividades de leitura de dois manuais didáticos de Inglês como Língua Estrangeira (I/LE). A análise pretende verificar se os exercícios de leitura propostos nestes manuais seguem as recomendações dos PCNs de LE. Como metodologia, foi adotada a análise documental sob a perspectiva da análise de conteúdos, de teor interpretativista e qualitativo. Foi concluído que, dos dois materiais analisados, apenas um adéqua-se ao proposto pelos PCNs.
\end{abstract}

Palavras-chave: ensino-aprendizagem; leitura; livro didático.

\begin{abstract}
This paper analyzes the reading activities in two textbooks used in English as a Foreign Language (EFL) classes to determine whether the activities in the materials follow the orientation found in the PCNs. The research was based on a document study, using a content analysis perspective and an interpretative and qualitative view. It was concluded that only one of the two textbooks fits the recommendations of the PCNs.

Keywords: teaching and learning; reading; textbook.
\end{abstract}

\section{PRIMEIRAS PALAVRAS}

O ensino de Língua Estrangeira (LE) no Brasil, segundo os Parâmetros Curriculares Nacionais (PCNs) de Língua Estrangeira, é visto como um processo ineficiente, tanto na rede pública quanto na rede privada de ensino, resultado de uma série de fatores que causam tal repercussão. Entre tais fatores, podemos citar a má escolha de um livro didático como um dos principais pontos.

Tendo em vista o foco na leitura proposto pelos PCNs, a escolha do material didático deve ser feita com muita cautela, pois existem diferentes abordagens e métodos para o ensino de LE. Além disso, é comum encontrarmos materiais que, segundo seus autores, são formulados de acordo com os PCNs, porém, ao analisarmos as atividades propostas, podemos 
perceber que as mesmas e os exercícios sugeridos, em sua grande maioria, são contraditórios às orientações apresentadas pelo documento elaborado pelo Ministério da Educação. Dentre essas orientações, encontram-se o ensino da língua a partir do uso e não da estrutura, a compreensão da linguagem a partir de sua natureza sociointeracional, a importância da relação entre a língua materna e a língua estrangeira durante a aprendizagem, a organização das aulas com base nos conhecimentos de mundo, léxico-sistêmico e textual, o foco na construção dos significados, etc.

Com base no quadro apresentado acima, pretendemos, neste artigo, analisar dois livros didáticos, desenvolvidos por diferentes editoras, ambos destinados à mesma série: $9^{\circ}$ ano do Ensino Fundamental. Procuraremos identificar a visão de linguagem, texto e os paradigmas de leitura por eles abordados e compará-los à proposta dos PCNs. Para tanto, primeiramente, apresentaremos alguns conceitos a respeito do que seja a linguagem e sua relação com o mundo real. Exporemos também apontamentos abarcando as noções de texto adotadas nas visões de linguagem elencadas, assim como a proposta bakhtiniana dos gêneros do discurso. Em seguida, mostraremos os três principais paradigmas de leitura e seus respectivos focos durante o processo. Após essa seção, desenvolveremos a metodologia, etapas que deverão ser seguidas para a análise dos livros didáticos It's a New Way 4 e Connect 4. E, por último, traremos a análise propriamente dita dos materiais selecionados.

\section{SOBRE A LINGUAGEM, O TEXTO E OS GÊNEROS DO DISCURSO}

Um dos grandes problemas do ensino de idiomas atualmente é o fato de que muitos dos livros didáticos publicados para o ensino de leitura - conforme proposto pelos PCNs - se encontram numa espécie de vácuo teórico, não se baseando numa visão de linguagem, texto e leitura condizentes com a proposta didática do próprio material. Nesta seção, apresentaremos uma breve discussão sobre algumas visões de linguagem e texto, além dos apontamentos de Bakhtin sobre os gêneros dos discursos para, em nossa análise, detectar o uso ou não de tais visões como embasamento da proposta dos livros.

Segundo Travaglia (1996), são 03 (três) as principais visões de linguagem: (1) linguagem como expressão do pensamento; (2) linguagem como instrumento de comunicação; e (3) linguagem como forma ou processo de interação.

A primeira visão, de linguagem como representação do pensamento, pondera que as pessoas não se expressam bem porque não pensam bem. Construímos a expressão no interior do pensamento, a exteriorização seria, então, uma espécie de tradução das idéias contidas na 
mente. Essa visão de linguagem nos apresenta um sujeito a-social e individualizado, pois enunciar é considerado um ato monológico, que não é afetado pela presença do outro nem pelas circunstâncias sociais.

Já a segunda concepção, a de linguagem como instrumento de comunicação, considera a linguagem como um conjunto de enunciados que, proferidos por um emissor, carregam uma mensagem a um receptor, tendo este o objetivo de analisar os enunciados para a decodificação do significado. De acordo com essa visão, para que o processo de leitura se realize, é importante o conhecimento do código lingüístico por ambos os participantes do ato - emissor e receptor. A característica social do sujeito é sua participação no processo de interlocução. É importante ressaltar que os significados já estão prontos na mensagem codificada pelo emissor, restando ao receptor a decodificação das mesmas.

Por último, na visão de linguagem como forma ou processo de interação, o indivíduo, ao fazer uso da língua(gem), não traduz e/ou exterioriza pensamentos, mas sim age e atua sobre o interlocutor. A linguagem é o espaço de “interação humana, de interação comunicativa por meio da produção de efeitos de sentido entre interlocutores em uma dada situação de comunicação e dentro de um contexto sócio-histórico e ideológico” (Travaglia, 1996:110).

Essa visão de linguagem é fundamentada nos escritos do filósofo da linguagem russo Mikhail Bakhtin por meio do conceito de dialogismo. Segundo o autor, a língua em sua totalidade concreta, viva, em seu uso real, tem a propriedade de ser dialógica. Essa propriedade vai além do diálogo face a face e existe em todas as esferas da comunicação humana. Para o filósofo, todo discurso é, indiscutivelmente, ocupado e atravessado pelo discurso alheio, ou seja, o discurso de um está sempre atravessado pelo discurso de outrem (cf. Bakhtin, 2006). A linguagem passa, então, a ser vista como o ponto de tensão e interação entre as vozes sociais. Para Bakhtin, a enunciação e prática social são conceitos intrínsecos, interligados, sendo que, desta maneira, o ato de enunciação é, na verdade, uma forma de agir no mundo.

É importante ressaltar que a visão sociointeracional da linguagem com base nos estudos bakhtinianos é a adotada, como já dito em nossa introdução, pelos PCNs de LE, ao postular que

o uso da linguagem (tanto verbal quanto visual) é essencialmente determinado pela sua natureza sociointeracional, pois quem a usa considera aquele a quem se dirige ou quem produziu o enunciado. Todo significado é dialógico, isto é, é construído pelos participantes do discurso. Além disso, todo encontro interacional é crucialmente marcado pelo mundo social que o envolve: pela instituição, pela cultura e pela história (BRASIL, 1998:27). 
As visões de linguagem aqui elencadas derivam-se em diferentes visões de texto. Para Koch (2006) são três os principais conceitos de texto: (1) o texto como representação mental do pensamento; (2) o texto como um simples produto de codificação de um emissor a ser decodificado por um leitor/ouvinte; e (3) o texto como lugar da interação.

$\mathrm{Na}$ concepção de linguagem como representação do pensamento, o texto é a materialização da representação do conteúdo mental do autor, restando ao receptor do mesmo entender tal representação exercendo, pois, um papel passivo no processo de leitura. Na concepção de linguagem como código, o texto é apenas um produto da codificação de um emissor que deve ser decodificado pelo leitor/ouvinte. Para que isso ocorra é preciso que os participantes do processo de leitura conheçam o código. Nesta abordagem, o decodificador também exerce um papel passivo. Já na concepção interacional ou dialógica da linguagem, o texto é enxergado como o lugar da interação entre os interlocutores, sujeitos ativos no processo da leitura e os significados se constroem e são construídos na interação autor, texto e leitor.

Novamente evocamos Bakhtin (2003:307) que nos ensina que o “(...) texto no sentido amplo é entendido como qualquer conjunto coerente de signos, assim como a ciência das artes (musicologia, a teoria e a história das artes plásticas) opera com textos (obras de arte)...”.

O texto deixa, então, de ser visto somente como um construto linguístico e passa a ser abordado como uma unidade de sentidos construídos por meio de linguagens verbais e/ou não-verbais. Para este autor, a noção de texto deve estar intimamente ligada à noção de enunciação, esta entendida como um produto das relações sociais. Textos surgem em contextos sócio-históricos específicos e são construídos com certos propósitos sóciocomunicativos, estando seus significados além deles, nos discursos que os originam e compõem, assim como naqueles que o texto precede (cf. Bakhtin, 2003 e 2006). Tais discursos são apresentados dialogicamente e o texto concretiza-se como um produto da interação entre diferentes vozes sociais.

Ainda segundo Bakhtin, os textos não são homogêneos, mas sim constituídos em "tipos relativamente estáveis de um enunciado” (2003:279), ou seja, em diferentes gêneros do discurso. Os gêneros são, para o filósofo, "modelos tipológicos de construção da totalidade discursiva" (p. 334) e podem ser classificados como pertencendo a dois tipos: os gêneros primários e os gêneros secundários. Os primários são os de alcance imediato, isto é, ligados às situações sociais cotidianas como a conversa face a face, cartas, diálogos, etc. Os gêneros secundários são considerados mais complexos e referem-se a outras esferas de interação social, tais como o discurso científico, filosófico, literário, etc. Os primeiros tipos são, 
normalmente, adquiridos na vida cotidiana, enquanto os gêneros secundários, geralmente, dependem do processo de letramento para serem alcançados e compreendidos. Ambos são padrões comunicativos usados socialmente, ou seja, utilizamos diferentes gêneros discursivos que, por sua vez, exercem uma função social entre os membros de nossa comunidade.

Deve fazer parte do trabalho com a educação o manejo de diferentes gêneros do discurso, pois é habituando-nos a utilizar diferentes gêneros que nos tornamos capazes de interagir no mundo, nas mais diversas esferas sociais. Portanto, procuraremos identificar também nos livros elencados como corpus para nossa análise, a pluralidade no trabalho de leitura com os gêneros e de que forma este trabalho é realizado. Para tanto, apresentaremos em nossa próxima seção alguns paradigmas de leitura pertinentes à investigação proposta.

\section{PARADIGMAS DE LEITURA: OLHARES MÚLTIPLOS}

Todas as concepções apresentadas acima sobre linguagem, texto e gêneros do discurso resultam em diferentes concepções de leitura. São elas: (1) foco no autor; (2) foco no texto; e (3) foco na interação (psicolinguística e social).

Na concepção de leitura com o foco no autor, segundo Koch (2008), o texto é visto como um produto da representação mental do pensamento do autor, isto significa dizer que o leitor não participa no processo de construção de sentidos do texto, pois sua função é captar a representação mental e as intenções do autor, portanto o receptor exerce um papel totalmente passivo. Essa visão de leitura se baseia na concepção de linguagem como representação do pensamento e de texto como exteriorização desse pensamento uma vez que cabe ao leitor o papel de extrair o conteúdo mental expresso pelo autor.

Ainda de acordo com Koch, o segundo paradigma de leitura, foco no texto, por sua vez, baseia-se na concepção de língua como código, ou seja, instrumento de comunicação e da noção de texto como um produto da codificação de um emissor que deve ser decodificado pelo leitor. Logo, o processo de leitura é percebido como um ato passivo de codificação e decodificação de mensagens. Para tanto, é necessário que ambos os participantes, emissor e receptor, conheçam o código (instrumento) utilizado.

Já o terceiro paradigma de leitura, foco na interação, que se baseia na visão de linguagem como interação e do texto como o lugar da interação, é estudado por dois diferentes ângulos: a visão psicolinguística (autor-texto-leitor) e a visão sociointeracionista (autor-texto-leitor-leitores e contexto social). 
Para Leffa (1999) a interação sob o enfoque psicolinguístico enxerga a leitura como um processo no qual o leitor transaciona com o autor por meio do texto, num contexto específico, com intenções específicas. Em outras palavras, o sentido do texto é construído pelo autor ao escrevê-lo e pelo leitor ao lê-lo. Durante esse processo, diversos tipos de conhecimento são necessários para o processamento da leitura, tais como: lexical, sintático, semântico, textual, enciclopédico, etc. Quando, no ato de construção de significações, um desses tipos de conhecimento falha, outro é acionado para continuar o processo de leitura.

Por outro lado, a interação sob o enfoque social vê a leitura como um processo sóciohistórico no qual se dá ênfase às vozes de outros localizados na estrutura dialógica da linguagem. Para este enfoque, o significado não está nem no texto, nem no leitor, mas nas convenções de interação social em que ocorre o ato da leitura (cf. Leffa, 1999). É a visão sociointeracional da linguagem e de leitura que embasa os Parâmetros Curriculares Nacionais para o ensino de Língua Estrangeira (1998), como já mencionado.

Segundo esse documento, a visão sociointeracional da linguagem permite o desenvolvimento de temas tais como: cidadania, a consciência crítica em relação à linguagem e os aspectos sociopolíticos da aprendizagem de uma língua estrangeira (LE). Por meio de um ensino baseado nessa concepção, permitir-se-á ao aluno o engajamento discursivo em diferentes práticas sociais. Ainda segundo os PCNs, estão envolvidos no processo de construção de significados três tipos de conhecimentos essenciais: o conhecimento léxicosistêmico (relacionado aos níveis de organização linguística das pessoas); o conhecimento de mundo (refere-se ao pré-conhecimento sobre as coisas do mundo); e conhecimento da organização social (rotinas interacionais que usamos para organizar as informações em textos escritos e/ou orais).

\section{METODOLOGIA DE PESQUISA}

\section{Tipo de pesquisa}

Para a realização da análise aqui proposta, nos basearemos numa visão interpretativista da pesquisa qualitativa. Segundo Moita Lopes (1994), a visão interpretativista considera que os significados que caracterizam o mundo social são construídos pelo homem, que interpreta e (re-)interpreta o mundo a sua volta, fazendo assim com que não haja uma realidade única, mas várias realidades. Ou seja, ignoram-se significados considerados corretos e padrões e dá-se margem a interpretação dos resultados. 
Optamos por realizar essa interpretação por meio de uma análise documental, na qual se consideram como corpus vários tipos de documentos: cartas, diários, textos oficiais, livros didáticos, entre outros (cf. Lüdke e André, 2005). A análise de conteúdo (AC) proposta por Bauer (2008), nos servirá como enfoque analítico. Utiliza-se a AC como uma técnica para produzir inferências de um texto focal levando em conta o seu contexto social de maneira objetivada.

\section{Descrição do corpus}

Analisaremos dois livros didáticos em circulação no território nacional, a saber: Connect 4 (2010) e It's a New Way 4 (2010). Foram escolhidos esses livros por se tratarem de obras destinadas ao uso didático em escolas regulares no nono ano do Ensino Fundamental. Além disso, levaremos em conta que o primeiro é publicado por uma editora internacional (Cambridge) e o segundo é publicado por uma editora nacional (New Way).

O quadro abaixo sintetiza os livros didáticos escolhidos, ressaltando a variedade do inglês que o material se propõe a ensinar, destacando o nível, o objetivo e o público-alvo dos respectivos títulos, além da editora que os publica e a data de publicação.

\begin{tabular}{|c|c|c|c|c|c|c|}
\hline Série & Título & Nível & Objetivo & $\begin{array}{l}\text { Público- } \\
\text { alvo }\end{array}$ & $\begin{array}{l}\text { Editor } \\
\text { a }\end{array}$ & Data \\
\hline $\begin{array}{l}9^{\circ} \text { ano do } \\
\text { Ensino } \\
\text { Fundamental }\end{array}$ & $\begin{array}{ll}\text { It's } \quad \text { a } \\
\text { New } \\
\text { Way } 4\end{array}$ & $\begin{array}{l}\text { Pré- } \\
\text { interme } \\
\text { diário }\end{array}$ & $\begin{array}{l}\text { Desenvolver } \\
\text { a habilidade } \\
\text { de leitura e } \\
\text { compreensão } \\
\text { de textos. }\end{array}$ & $\begin{array}{l}\text { Alunos de } \\
\text { inglês } \\
\text { como } \\
\text { língua } \\
\text { estrangeira }\end{array}$ & $\begin{array}{l}\text { New } \\
\text { Way }\end{array}$ & 2010 \\
\hline $\begin{array}{l}9^{\circ} \text { ano do } \\
\text { Ensino } \\
\text { Fundamental }\end{array}$ & $\begin{array}{l}\text { Connect } \\
4\end{array}$ & $\begin{array}{l}\text { Pré- } \\
\text { interme } \\
\text { diário }\end{array}$ & $\begin{array}{l}\text { Desenvolver } \\
\text { a habilidade } \\
\text { de } \\
\text { compreensão } \\
\text { e produção } \\
\text { de textos } \\
\text { orais a } \\
\text { escritos. }\end{array}$ & $\begin{array}{l}\text { Alunos de } \\
\text { inglês } \\
\text { como } \\
\text { língua } \\
\text { estrangeira }\end{array}$ & $\begin{array}{l}\text { Cambri } \\
\text { dge }\end{array}$ & 2010 \\
\hline
\end{tabular}

Tabela 1: Descrição dos materiais selecionados para a análise. 


\section{Procedimentos de análise}

Para realizarmos a análise aqui proposta seguiremos as seguintes etapas: (1) apresentação do material identificando a proposta metodológica adotada; (2) apresentação das unidades procurando localizar o espaço destinado à leitura; e (3) identificação do paradigma de leitura adotado pelo material.

\section{ANÁLISE DOS MATERIAIS DIDÁTICOS}

O livro Connect (2010), publicado pela editora Cambridge, é uma coleção desenvolvida para os $3^{\circ}$ e $4^{\circ}$ ciclos do Ensino Fundamental brasileiro e dividida em quatro volumes, um para cada série do segmento. A obra aspira a desenvolver a habilidade de compreensão e produção de textos orais e escritos em inglês por meio de diversas atividades.

Connect 4 é dividido em oito unidades, sendo que cada uma delas é subdividida em quatro lições. Algumas dessas são iniciadas ou por um texto, geralmente um diálogo, ou por algum exercício que objetiva a desenvolver o vocabulário do aluno referente ao tema tratado no capítulo. É importante ressaltar que, mesmo nas lições iniciadas por textos, não há a proposição de quaisquer exercícios de interpretação dos mesmos. As lições iniciadas por textos são, geralmente, seguidas por pontos gramaticais e, em seguida, exercícios para a fixação do conteúdo adquirido. No que se refere às lições iniciadas com foco no vocabulário, elas são seguidas por exercícios estruturais do tipo “Complete...”, “Associe...” etc. É perceptível que a outra grande parte das lições já se inicia com foco direto na gramática e nos exercícios gramaticais.

No decorrer das lições, são propostas atividades que visam ao desenvolvimento das quatro habilidades linguísticas - ler, escrever, ouvir e falar. As habilidades orais são trabalhadas com exercícios em que o aluno escuta uma determinada situação - o CD vem juntamente ao livro - e ora completa exercícios do tipo "Verdadeiro ou Falso", ora marca uma das alternativas dadas para perguntas do tipo “Quem...”, “Quando...”. Para o desenvolvimento da habilidade de fala do aluno há dois tipos de exercícios: um chamado de "Pronunciation" em que os aprendizes escutam e, juntamente ao professor, percebem a silaba tônica, junção entre palavras, entonação etc., e, em seguida, repetem as frases expostas como exemplos com fins de prática enunciatória; há ainda atividades denominadas "Speaking” na qual os alunos trabalham em pares perguntando e respondendo a questões a partir de tópicos gramaticais pré- 
definidos na lição. Já as atividades que procuram trabalhar as habilidades escritas - leitura e produção - são do tipo “Complete”, “Transcreva”, "Reescreva”, “Combine as frases”.

Entre as quatro lições de cada unidade há uma revisão, nessa parte os conteúdos apresentados anteriormente são trabalhados por meio de exercícios diversos. Ao final da ultima lição, há a seção “Get connected”, essa parte é dividida em três etapas: a primeira, “Read”, propõe um texto e questões referentes a este para interpretação. Geralmente questões como "Responda”, “Assinale verdadeiro ou falso" ou "Circule a palavra correta”; a segunda etapa, “Listen”, é constituída por exercícios do tipo “Escute e responda” ou "Escute e marque verdadeiro ou falso"; e, por último, há a terceira etapa, "Write”, que propõe a redação de um parágrafo ou de um pequeno texto baseado em um roteiro apresentado na forma de questionário que o aluno deverá seguir para a elaboração do mesmo.

Esse material didático não trabalha com a noção de gêneros do discurso. Predominam os diálogos e textos por nós denominados didáticos, ou seja, textos redigidos especialmente para o material sem fins sociais e comunicativos fora dele. A temática desses textos é diversificada, e os mesmos não focam a realidade dos alunos, ou seja, há uma universalização dos temas trabalhados. Assuntos como "Como ser famoso e rico", "Vida de um adolescente famoso" ou "Um futuro emocionante" não são próximos à realidade da maioria dos alunos das escolas brasileiras. Além disso, o livro não trabalha com os temas transversais propostos pelos PCNs - ética, pluralidade cultural, meio ambiente, saúde, educação sexual, trabalho e consumo - em seus textos. Como consequência não existem propostas de discussões que abordem questões ideológicas.

Quando há diálogos, os conteúdos gramaticais são, inicialmente, expostos nos textos, porém são desenvolvidos separadamente, não havendo vínculo explícito entre tais conteúdos e a semântica textual. A gramática é apresentada em caixas textuais nas quais são exemplificados os usos do conteúdo abordado. Em seguida, são propostos exercícios estruturais do tipo: "Complete a conversa...", "Complete o e-mail..." e "Complete a mensagem...” etc., ou então exercícios do tipo “Escreva frases”, “Dê respostas completas”, na tentativa de estimular a competência escrita do aluno.

Para exemplificar o modo como o material trabalha com a leitura, examinaremos o exercício contido na página 26 do manual didático (cf. Anexo 1). Nesse exercício é proposto um texto informativo com curiosidades sobre como pode ser o futuro. São apresentadas algumas previsões que se referem principalmente a hotéis lunares, às mudanças na imprensa, a novos modos de se ter energia e ao fim dos carros movidos a combustível. O vocabulário do texto é simples, com a predominância do tempo verbal futuro simples. Ao longo do texto 
encontramos algumas passagens e expressões que funcionam como ganchos ("Do we have flying cars today?”) ou ainda que denotam um tom de informalidade ao mesmo (“And that's very exciting!”).

Inicialmente, antes da leitura do texto, pede-se que o aluno realize uma leitura rápida e marque, das opções dadas, o tema que não é tratado no texto, a saber: óculos de realidade virtual. Percebe-se como objetivo deste exercício o desenvolvimento da capacidade do aluno de separar os temas que são abordados no texto, porém, para alcançar a meta proposta, o aluno fará somente um movimento de skimming identificando no texto a alternativa que não é pertinente como conteúdo temático do mesmo.

A segunda atividade sugere que o aluno leia novamente o texto, desta vez de forma atenciosa, ao mesmo tempo ouvindo a faixa de áudio com o texto gravado no CD que acompanha o livro. Após a leitura e a escuta do texto, o estudante deverá voltar ao exercício A para conferir a resposta previamente dada. Não há no material explicitação de formas, técnicas ou modos para a realização dessa leitura, mas apenas o tempo sugerido (leitura rápida ou devagar). Formulações sobre estratégias de leitura também não foram encontradas.

Na terceira atividade, é solicitado aos alunos que circulem, dentre três diferentes alternativas, palavras ou expressões que completem as frases de modo que sejam coerentes com o tema tratado no texto. Na alternativa 1, por exemplo, encontramos a seguinte frase "In the future, we probably won’t have (newspapers / vídeo cell phones / new medicines)”, devese, então, retornar ao texto para verificar que a única alternativa descrita pelo mesmo como correta é a palavra “newspapers”. Novamente o aluno não é levado a refletir sobre o processo de leitura, nem a analisar ou interpretar o texto da lição, recorrendo apenas ao conteúdo que crê-se “presente no texto” para a solução do exercício.

É perceptível nesse material a predominância da leitura com foco no texto e, consequentemente, uma visão comunicativa de linguagem e texto. Nesta perspectiva, não há a necessidade de interação entre autor-texto-leitor ou autor-texto-leitor e outros leitores. O aluno deverá, como nos exercícios apresentados acima, somente extrair e localizar informações do texto. Este é, então, o produto codificado pelo autor que deve ser decodificado pelo leitor no processo de leitura.

Embora seja o foco no texto predominante no livro, nada impede que o professor proponha atividades extras que permitam a interação verbal oral ou escrita em sala de aula. Porém, é importante ressaltar que o manual do professor não apresenta indicações de tais atividades, cabendo ao mesmo a proposição de atividades didáticas para o trabalho com os textos do material adotado. 
Já o segundo livro, It's a New Way, publicado pela Editora New Way, desenvolvido para o Ensino Fundamental da rede pública brasileira é dividido em quatro volumes, como a coleção anterior, um para cada série do $3^{\circ}$ e $4^{\circ}$ ciclos. A obra tem por objetivo desenvolver a competência escrita por meio de atividades que buscam reflexão, autonomia e criatividade por parte do aluno.

It's a New Way 4 possui 88 páginas, é divido em 8 unidades, sendo que na quarta e na oitava são propostas atividades de revisão e consolidação de conteúdos expostos anteriormente. Antes da primeira unidade, há a apresentação dos personagens que percorrerão algumas das histórias ao longo do livro. São quatro personagens: três deles são americanos e um é brasileiro residente nos Estados Unidos. As unidades 1, 2, 3, 5, 6 e 7 são subdivididas em duas partes. Ambas as seções são iniciadas por alguma atividade de leitura. Durante essas atividades são propostas algumas questões do tipo "A que se referem os (...) acima”, "De que trata o primeiro texto" e "Com que finalidade (...) enviou a mensagem acima”.

Após a seção de leitura, geralmente é proposto um pequeno exercício que foca um ponto específico da gramática da língua inglesa. O objetivo desse exercício é apresentar o conteúdo gramatical que será sistematizado posteriormente. É importante ressaltar que a gramática trabalhada na seção normalmente encontra-se veiculada ao texto da mesma. Após sistematizar a gramática, são propostas algumas atividades para a compreensão do assunto estudado. Exercícios do tipo “Escreva frases”, “Complete os anúncios abaixo” e “Complete os diálogos” são comuns nessa etapa. Vale ressaltar que na segunda seção de cada unidade há uma parte chamada "Read More” em que os autores propõem atividades de leitura, interpretação e debate dos textos.

Ao longo das unidades são apresentados diversos gêneros textuais, tais como panfletos, anúncios, cartas, currículos, mapas, placas, cartões postais, folhetos, textos informativos, emails, diálogos, entre outros. Apesar da multiplicidade de gêneros, não são propostos exercícios ou explicações formais que levem o aluno a refletir sobre estilo, conteúdo temático e composicional, assim como funções comunicativas e sociais dos mesmos. Também não foram encontrados exercícios ou proposições teóricas que explicitassem os tipos textuais narrativo, argumentativo, expositivo, injuntivo e descritivo - apresentados pelo livro.

Os exercícios que seguem os textos ao longo do livro, com exceção do quadro "Read More” que apresentaremos a seguir, seguem um paradigma interacional psicolinguístico de leitura, ou seja, questões do tipo “A que se refere o texto”, “O que representa o quadro...” e “Em que países estão as duas amigas?” formuladas com o objetivo de relacionar o conhecimento prévio do leitor sobre o conteúdo ao próprio texto, são típicas nos exercícios 
analisados. É importante ressaltar ainda que, no decorrer das unidades, foram encontradas algumas atividades estruturais para a abordagem da gramática, tais como "Retire do texto um verbo...” e “Complete com o verbo no tempo...”.

Os alunos são expostos a diferentes temas a cada unidade. A maior parte dos assuntos são relacionados aos temas transversais propostos pelos PCNs - ética, pluralidade cultural, meio ambiente, saúde, educação sexual, trabalho e consumo - sendo, na maioria das vezes, tópicos próximos a realidade vivida pelos alunos: doenças, política, mercado de trabalho, meio ambiente, música, drogas, entre outros. A abordagem de temas em voga na sociedade brasileira é relevante, pois permite que o professor trabalhe, em sala de aula, predominantemente, com uma visão sociointeracionista de linguagem e leitura.

Apesar de encontrarmos alguns exercícios estruturais, como já apontado, no tocante ao ensino da gramática, predominam atividades contextualizadas que enfocam o uso da língua, tais como “Que conselho você daria para...”, “O que Jane deve fazer para manter uma boa saúde?” e "Faça um cartaz para uma campanha antidrogas na escola. Escreva seis sugestões...”, que por meio de proposições práticas direcionam os alunos a formularem enunciados de acordo com os conteúdos gramaticais apresentados na unidade.

Para exemplificar o modo como o material aborda a leitura, analisamos abaixo os exercícios de leitura da página 58 do material (cf. Anexo 2). Nesta página, os alunos têm acesso a um texto que conclama as pessoas a participarem de um projeto social, como voluntários, na assistência a crianças nas favelas da cidade do Rio de Janeiro. O texto é composto de vocabulário simples, informal, com predominância de substantivos, pronomes e verbos no tempo presente. Escrito com a intenção de engajar as pessoas no projeto social citado, o texto propõe que os futuros voluntários trabalhem com atividades como a dança, o teatro, esportes, artes, entre outros, que, segundo o texto, poderão mudar a vida das crianças assistidas pelo projeto. Além disso, são apresentadas informações relevantes para aqueles que pretendem se candidatar ao programa.

Para esse texto são propostas três atividades que abrangem uma grande gama de conteúdos. Na primeira, pede-se que o aluno responda a duas perguntas, tendo a primeira a meta de investigar se o educando conseguiu inferir o objetivo do texto. Já na segunda questão, pergunta-se sobre os tipos de trabalho que um voluntário poderá desenvolver junto às crianças e, além disso, os alunos são levados a refletir sobre a eficácia desse trabalho. Nas duas questões, é importante observar que, além do conhecimento linguístico, há a necessidade de serem ativados conhecimentos de organização textual e de mundo para a solução das mesmas. 
Na segunda atividade, são propostas três perguntas e pede-se que o aluno escolha ou marque aquelas que podem ser respondidas no texto. O estudante deverá recorrer ao texto para identificar que a informação que não pode ser inferida a partir do mesmo é a referente ao nível de escolaridade daqueles que pretendem candidatar-se como voluntários do projeto.

No terceiro exercício são propostos alguns pontos para a discussão em sala de aula. Perguntas como "Você já participou de algum tipo de trabalho voluntário? Como foi a experiência?”, “Que tipo de serviço voluntário você gostaria de prestar?” e “Como a escola pode participar desse tipo de trabalho?” fazem com que haja possibilidade de interação entre o conteúdo temático do texto e as idéias que circulam na sociedade, em especial, no conhecimento de mundo dos alunos, tornando o texto significativo para os mesmos e coconstruindo, em sala de aula, a consciência crítica dos estudantes sobre o tema "Projetos Sociais”.

Pode-se afirmar que o material se baseia, prioritariamente, numa visão interacional de linguagem, texto e leitura, seja ela psicolinguística ou sociointeracional. Em quase todas as unidades, conhecimentos prévios são ativados durante o processo de construção de significação que acontece na interação entre autor-texto-leitor, ou seja, é evidente a utilização do paradigma psicolinguístico de leitura. Porém, o livro também adota atividades que levantam questões ideológicas e sociais, promovendo discussões e o contato com o outro seja o outro imediato como o professor e outros alunos, ou participantes não tão imediatos por meio de opiniões cristalizadas nas estruturas dialógicas da linguagem. Essas atividades, então, enquadram-se numa perspectiva sociointeracional de leitura.

\section{CONSIDERAÇÕES FINAIS}

Ao propormos analisar os dois manuais selecionados, It's a new way 4 e Connect 4, procuramos levantar a abordagem de linguagem e de leitura adotada pelos mesmos e se tais abordagens enquadravam-se na visão de linguagem e leitura proposta pelos PCNs. Para tanto, recorremos à análise documental e a análise de conteúdos que, por meio de uma abordagem interpretativista e qualitativa, permitiram-nos o levantamento de considerações e um olhar reflexivo sobre as obras citadas.

Pudemos verificar, então, que o primeiro material analisado, o livro Connect 4, adota seções de leitura com foco no texto. Nessas seções o aluno deve apenas decodificar significados existentes na estrutura textual, não havendo, de fato, um processo de interpretação textual e de construção dos sentidos. Já o segundo material, It’s a New Way 4, 
baseia-se numa visão interacional de linguagem e leitura. Nesse livro, são diversas as propostas que incentivam a interação entre autor-texto-leitor e autor-texto-leitor-leitores e contexto sócio-histórico.

Finalmente, pudemos concluir que somente o segundo material analisado, o livro It's a New Way 4, enquadra-se nas orientações dos PCNs, fornecendo, assim, contexto para que o professor incentive a interação no processo de leitura bem como o engajamento social em diferentes atividades pelo ensino do inglês como língua estrangeira, conforme sugerido pelas orientações do Ministério da Educação brasileiro.

Apontamos, ainda, que a análise aqui apresentada configura-se somente como uma leitura possível dos manuais selecionados. Fica aqui, então, conforme os apontamentos de Bakhtin (2003), que nos guiou durante toda a leitura realizada, nossa voz que, sendo precedida por outras nas quais nos embasamos, espera também suscitar respostas/indagações e, na esfera acadêmica, futuras investigações.

\section{REFERÊNCIAS}

Bakhtin, M. (Volochínov). (2006). Marxismo e filosofia da linguagem. São Paulo: Hucitec.

Bakhtin, M. (2003). Estética da criação verbal. São Paulo: Martins Fontes.

Bauer, M. \& W.Gaskell, G. (2008). Pesquisa qualitativa com texto, imagem e som: um manual prático. Petrópolis: Vozes.

BRASIL, Ministério da Educação, Secretaria de Educação. (1998). Parâmetros Curriculares Nacionais de Língua Estrangeira Moderna. Ministério da Educação. Secretaria de Educação - Brasília: Ministério da Educação.

Faraco, C. A. (2009). Linguagem e diálogo: as idéias lingüísticas do Círculo de Bakhtin. São Paulo: Parábola Editorial.

Goulart, A. J. A. \& Silva, M. Â. da. (2010). It’s a new way 4. Rio de Janeiro: New Way.

Koch, I. V. K. (2008). As tramas do texto. São Paulo: Editora Nova Fronteira. . (2006). Desvendando os segredos do texto. São Paulo: Cortez Editora.

Leffa, V. J. (1999). Perspectivas no estudo da leitura: texto, leitor e interação social. Pelotas: Educat.

Ludke, M. \& Andre, M. E. D. A. (2005). Pesquisa em educação: abordagens qualitativas. São Paulo: Editora Pedagógica e Universitária. 
Moita Lopes, L. P. da. (1994). Pesquisa interpretativista em linguística aplicada: a linguagem como condição e solução. In: D.E.L.T.A., vol. 10, nº 02, 1994, pág. 329-338.

Richards, J. C. et al. (2010). Connect 4. Cambridge: Cambridge University Press.

Travaglia, L. C. (1996). Ensino de gramática numa perspectiva textual interativa. In: Azambuja, J. Q. (Org.) O ensino de língua portuguesa para o 2 grau. Uberlândia: EDUFU.

\section{OS AUTORES}

Marcel Alvaro de Amorim é Licenciado em Letras, especialista em Filosofia da Linguagem e Mestre em Linguística Aplicada pela Universidade Federal do Rio de Janeiro. É professor do curso de Letras do Centro Universitário de Volta Redonda e cursa a especialização em Educação à Distância pela Universidade Federal Fluminense.

E-mail: marceldeamorim@yahoo.com.br

Alvaro Monteiro Carvalho é Licenciado em Letras pelo Centro Universitário de Volta Redonda e Mestrando em Linguística Aplicada pela Universidade Federal do Rio de Janeiro. É professor da rede municipal da cidade de Barra Mansa, onde atua como professor de Língua Inglesa, e do Instituto Brasil-Estados Unidos - IBEU.

E-mail: alvaroxxii@yahoo.com.br 


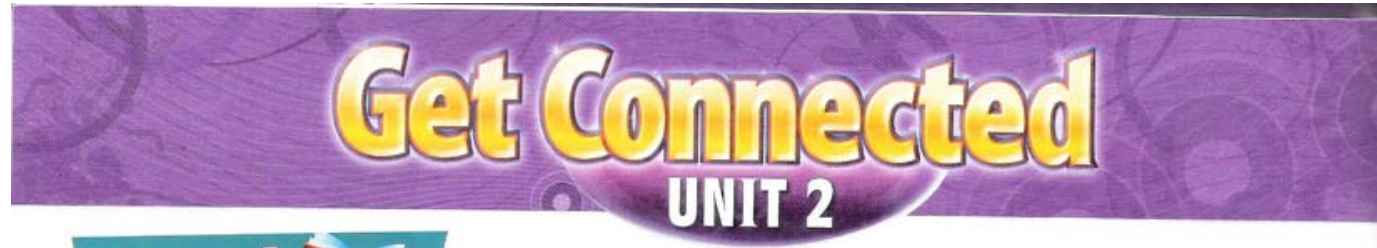

Read

A Read the Web site quickly. Check $(\checkmark)$ one thing the Web site does not talk about.

$\square$ a flying car $\square$ electricity from the sun $\square$ newspapers

$\square$ medicines $\square$ virtual reality glasses

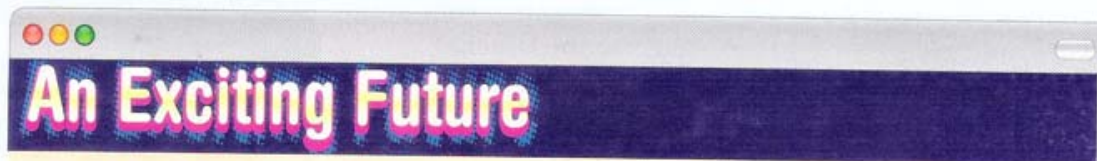

"First Flying Car Made," say the newspaper headlines! Do we have flying cars today? No, we don't. But in the future, that might be a newspaper headline. However, we probably won't have newspapers in the future. We'll get all our news on video cell phones.

So what will our world look like 10,20 , or 50 years from now? One Web site makes predictions about the future and writes articles about the future. Its prediction for August 23, 2025, reads: The first hotel on the moon finally opens. But predictions about the future are difficult. Will people go to the moon for their vacations? They might. Will we find new medicines and cure terrible sicknesses? We probably will. Will our homes use electricity from the sun and wind? Yes, they will. And we won't clean our houses - robots will do this - and cars won't need gas anymore.

We don't know these things for sure. But one thing is certain ... our lives in the future will be different from now. And that's very exciting!
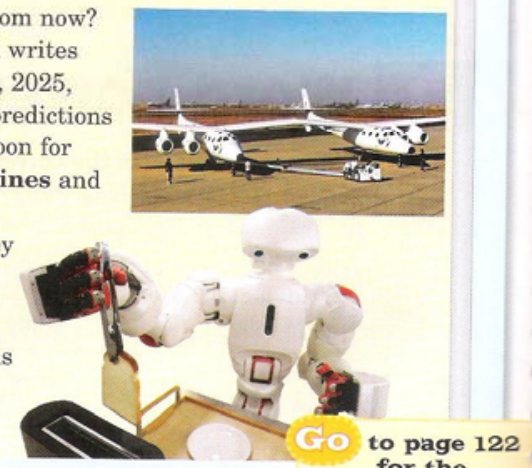

$B$ Read the Web site slowly. Check your answer in Part A.

C Circle the correct words to complete the sentences or the correct answers.

1. In the future we probably won't have (newspapers/video cell phones / new medicines).

2. A headline for 2025 predicts we will have (flying cars / terrible sicknesses / hotels on the moon).

3. In the future our homes will get electricity from (the sun and wind the moon / robots).

4. In the future we won't (drive our cars / clean our homes/ use medicines).

5. Will our lives be different in the future? (Yes, probably. / No. Not at all. / Yes, they will.) 
ANEXO 02

This is your chance to support some children from a number of Rio's favelas (urban slums). Working with them, you can help shape their lives by helping out with different recreational activities.

From dance and theatre to sports and arts and crafts, your input will help to stimulate and educate the children, giving them a positive focus. Project resources are limited, so your help could make a huge difference.

Factfile

- Placement fee: $£ 1145.00$ for 4 weeks, $£ 150.00$ for every week thereafter.

- Accommodation: guesthouse hotel, shared rooms - included in placement fee.

- Meals: not provided - self catering.

- Items not included: flight, insurance and visa costs In-country transport

(except airport pickup on arrival date).

- Activities: recreational activities, music, dance, arts and crafts, sports, theatre workshops, helping prepare food for the children, and generally assisting with educational development.

- Working Hours: hours will vary depending on project, but expect an average of 3 hours a day,

from the hours 8 am to $5 p m$.

- Requirements: experience working with children is preferred but not essential.

(adapted from the site: http://mww.i-to-i.com/placements/567 - August 22, 2007)

1 Responda às perguntas.

A Qual é o objetivo do texto acima?

B Que tipo de trabalho deverá o voluntário desenvolver junto às crianças carentes? Você acredita na eficácia desse trabalho? Justifique.

2 Marque as perguntas cujas respostas podem ser encontradas no texto acima.

( ) O voluntário terá direito a hospedagem gratuita?

( ) Quantas horas diárias o voluntário terá de trabalhar?

( ) Qual é o grau de escolaridade mínimo exigido para um voluntário engajar-se no projeto?

3 Para discussão em grupo:

A Você já participou de algum tipo de trabalho voluntário? Como foi a experiência?

B Que tipo de serviço voluntário você gostaria de prestar?

c Que vantagens e desvantagens você vê no trabalho voluntário?

D Como a escola pode participar desse tipo de trabalho? 